\title{
Combinatorial metabolic engineering of industrial Gluconobacter oxydans DSM2343 for boosting 5-keto-D-gluconic acid accumulation
}

\author{
Jianfeng Yuan, Mianbin Wu, Jianping Lin ${ }^{*}$ and Lirong Yang
}

\begin{abstract}
Background: L-(+)-tartaric acid (L-TA) is an important organic acid, which is produced from the cream of tartar or stereospecific hydrolysis of the cis-epoxysuccinate. The former method is limited by the availability of raw material and the latter is dependent on the petrochemical material. Thus, new processes for the economical preparation of L-TA from carbohydrate or renewable resource would be much more attractive. Production of 5-keto-D-gluconate (5-KGA) from glucose by Gluconobacter oxydans is the first step to produce L-TA. The aim of this work is to enhance 5-KGA accumulation using combinatorial metabolic engineering strategies in G. oxydans. The sldAB gene, encoding sorbitol dehydrogenase, was overexpressed in an industrial strain G. oxydans ZJU2 under a carefully selected promoter, $\mathrm{P}_{0169}$. To enhance the efficiency of the oxidation by $s / d A B$, the coenzyme pyrroloquinoline quinone (PQQ) and respiratory chain were engineered. Besides, the role in $s / d A B$ overexpression, coenzyme and respiratory chain engineering and their subsequent effects on 5-KGA production were investigated.

Results: An efficient, stable recombinant strain was constructed, whereas the 5-KGA production could be enhanced. By self-overexpressing the s/dAB gene in G. oxydans ZJU2 under the constitutive promoter $P_{0169}$, the resulting strain, G. oxydans ZJU3, produced $122.48 \pm 0.41 \mathrm{~g} / \mathrm{L}$ of 5-KGA. Furthermore, through the coenzyme and respiratory chain engineering, the titer and productivity of 5-KGA reached $144.52 \pm 2.94 \mathrm{~g} / \mathrm{L}$ and $2.26 \mathrm{~g} /(\mathrm{L} \cdot \mathrm{h})$, respectively, in a $15 \mathrm{~L}$ fermenter. It could be further improved the 5-KGA titer by $12.10 \%$ through the fed-batch fermentation under the $\mathrm{pH}$ shift and dissolved oxygen tension (DOT) control condition, obtained $162 \pm 2.12 \mathrm{~g} / \mathrm{L}$ with the productivity of $2.53 \mathrm{~g} /(\mathrm{L} \cdot \mathrm{h})$ within $64 \mathrm{~h}$.
\end{abstract}

Conclusions: The 5-KGA production could be significantly enhanced with the combinatorial metabolic engineering strategy in Gluconobacter strain, including sldAB overexpression, coenzyme and respiratory chain engineering. Fed-batch fermentation could further enlarge the positive effect and increase the 5-KGA production. All of these demonstrated that the robust recombinant strain can efficiently produce 5-KGA in larger scale to fulfill the industrial production of L-TA from 5-KGA.

Keywords: 5-keto-D-gluconate, L-(+)-tartaric acid, Pyrroloquinoline quinone, Respiratory chain, Fed-batch fermentation

\footnotetext{
* Correspondence: linjp@zju.edu.cn

Key Laboratory of Biomass Chemical Engineering of the Ministry of

Education,College of Chemical and Biological Engineering, Zhejiang

University, Hangzhou 310027, China
}

(C) 2016 Yuan et al. Open Access This article is distributed under the terms of the Creative Commons Attribution 4.0 International License (http://creativecommons.org/licenses/by/4.0/), which permits unrestricted use, distribution, and reproduction in any medium, provided you give appropriate credit to the original author(s) and the source, provide a link to the Creative Commons license, and indicate if changes were made. The Creative Commons Public Domain Dedication waiver (http://creativecommons.org/publicdomain/zero/1.0/) applies to the data made available in this article, unless otherwise stated. 


\section{Background}

L-(+)-tartaric acid (L-TA), an important naturally existing hydroxyl carboxylic acid, is mainly used as antioxidant in food industry, as a chiral reagent in organic synthesis, as an acidic reducing agent in the textile industry and in galvanochemistry [1-3]. It is also an alternative to citric acid as an acidulant in food additives for its superior organoleptic properties [4]. Currently, the LTA that is commercially available is produced exclusively through the stereospecific hydrolysis of cis-epoxysuccinate [5-7]. In this process, the reaction is catalyzed by the cis-epoxysuccinate hydrolase from Rhodococcus rhodochrous, Nocardia tartaricans, Corynebacterium sp. or Pseudomonas sp. [7]. However, cis-epoxysuccinate is derived from petrochemical-based precursor maleic anhydride, and this limits the production of L-TA. Therefore, development of the sustainable alternative solution for LTA manufacture has recently attracted increasing attention.

A promising route has been employed for the production of L-TA by sequential whole-cell catalyzed oxidation and chemical catalysis, in which the glucose was first biologically converted to 5-keto-D-gluconate (5-KGA) by Gluconobacter oxydans, then to L-TA in the presence of ammonium vanadate as a trace element $[4,8]$. Thus, the strategy towards an efficient synthetic route to L-TA was to optimize the enzymatic production of 5-KGA [4, 9].
Through genomic analyses, the genome sequence of G. oxydans $621 \mathrm{H}$ has been published, which leads to new insights into its metabolic pathway [10]. The essential genetic elements related to 5-KGA metabolism have been systematically identified (Fig. 1). The membranebound glucose dehydrogenase (mGDH, GOX0265), a quinoprotein containing pyrroloquinoline quinone (PQQ), oxidizes D-glucose to $\mathrm{D}$-glucono- $\delta$-lactone, which is subsequently converted to gluconic acid (GA) spontaneously or by gluconolactonase [11-13]. GA can be further oxidized to 5-KGA or 2-keto-D-gluconate (2-KGA) by PQQ-dependent sorbitol dehydrogenase (SLDH, GOX0854-0855) or FAD-dependent gluconate 2-dehydrogenase (GA2DH, GOX1230-1232), which transfer electrons from glucose to the respiratory chain ubiquinone and then to terminal ubiquinol oxidases to generate the proton motive force $[10,14]$. PQQ, heme $c$ or FAD serve as prosthetic groups [15, 16].

So far several attempts have been made to increase 5KGA production, such as overexpression of gluconate: NADP 5-oxidoreductase [9], inactivation of GA2DH [3, 17] and overexpression of SLDH $[18,19]$ and optimization of the media conditions [20]. The highest yield achieved of 5KGA was 240-295 mM (about $60 \mathrm{~g} / \mathrm{L}$ ) in a batch fermentation over periods as long as $72 \mathrm{~h}$ with a productivity of $0.83 \mathrm{~g} /(\mathrm{L} \cdot \mathrm{h})$ [18]. However, the methods used are

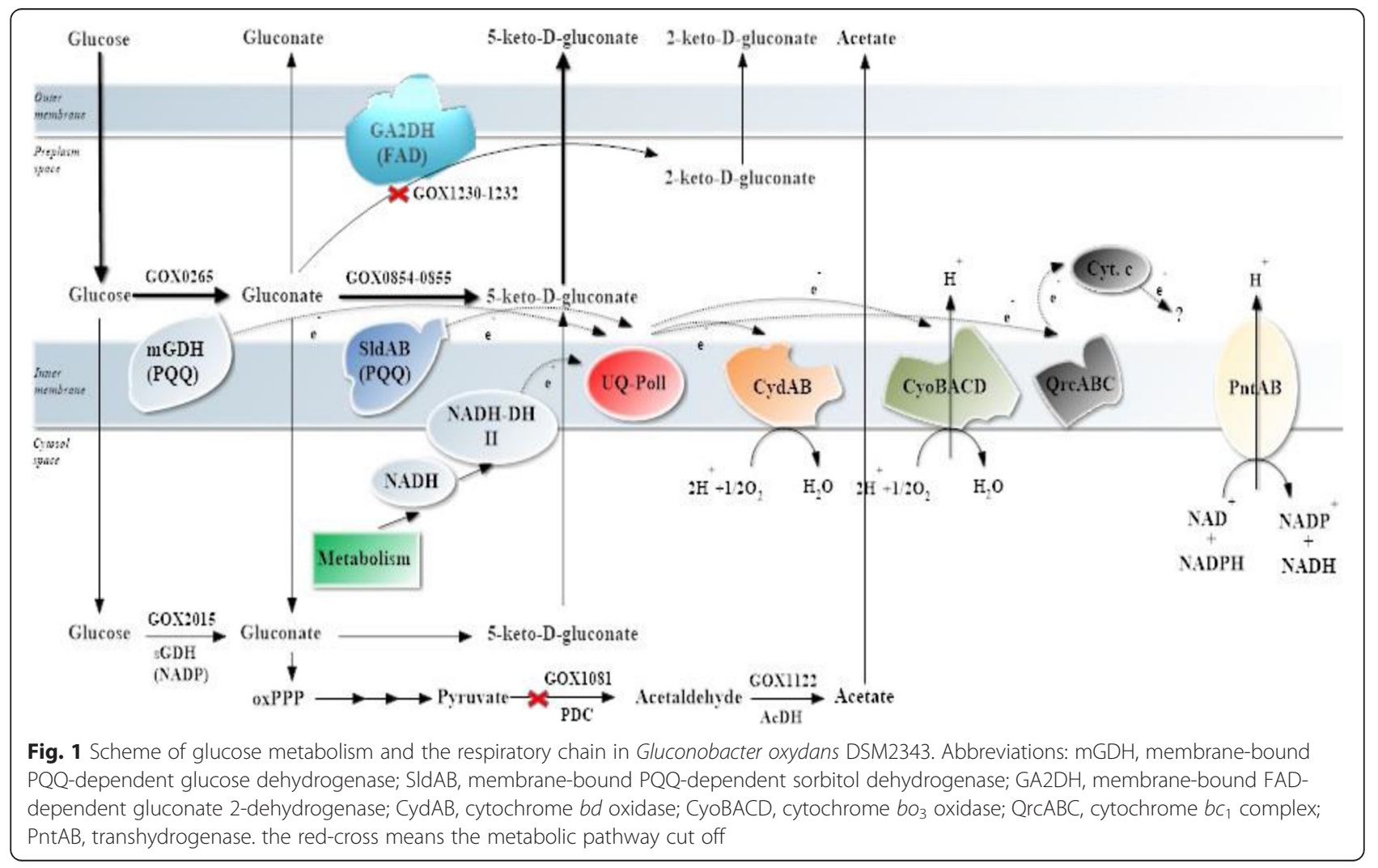


individual engineering approaches and the efficiency of 5KGA production was unsatisfactory, especially there was a large amount of residual GA left at the end of the biotransformation process.

In early work, we constructed the recombinant strain G. oxydans ZJU2, in which the GOX1231 and GOX1081 genes were markerless deleted [21]. The engineering of 2-KGA and acetic acid metabolism pathway could enhanced the 5-KGA production, but the titer and productivity of 5-KGA was unsatisfied. Hence, we set out to develop an efficient Gluconobacter cell factory to facilitate 5-KGA biosynthesis using combinatorial strategies. The sld $A B$ gene, encoding the SLDH, was plasmid-based overexpressed with a strong promoter, $\mathrm{P}_{0169}$ [22]. Inspired by the mechanism from most of the Gluconobacter, it is proposed that the cofactor PQQ and respiratory chain engineering could be enhanced efficiency of the membrane-bound quinoaproteins. As a result, the genes involved with the PQQ cluster $[23,24]$ and terminal ubiquinol cytochrome $\mathrm{bo}_{3}$ oxidase [25] were fused expression. The related specific enzyme activity, $\mathrm{H}^{+} / \mathrm{O}$ ratio and 5-KGA titer were investigated. Base on the $\mathrm{pH}$ shift and dissolved oxygen tension (DOT) control, the robust G. oxydans cells were more facilitated 5-KGA accumulation by the fed-batch fermentation. This study represents combinatorial engineering approaches collectively increased the titer of 5-KGA in the G. oxydans, which can provide insights into devising engineering strategies to improve the object production.

\section{Results and discussion}

\section{Promoter selection in G. oxydans strain}

Increasing interest in Gluconobacter has led to investigations on strain improvement. The well characterized promoter is a prerequisite to the understanding of gene expression. So far, a few studies concerning the isolation and characterization of $G$. oxydans promoters, such as $\mathrm{P}_{0169}$ [22], $\mathrm{P}_{\text {tufB }}$ [26], $\mathrm{P}_{0264}$ [27], and $\mathrm{P}_{0452}$ [27], have been reported. However, which one is more suit for gene expression in G. oxydans is inconclusive. To select the appropriate promoter for gene expression in G. oxydans, we generated the different promoters in front of a $g f p$ report gene in a pBBR1MCS5 vector. The promoter activity was indirectly determined by measuring the whole cell fluorescence intensity $\left(\mathrm{RFU} / \mathrm{OD}_{600}\right)$. As shown in Fig. 2, the RFU/OD 600 presented a linear increase with the cell growth until $24 \mathrm{~h}$. Green fluorescent protein (GFP) contains a fluorescent cyclic tri-peptide, and oxygen is required for the final oxidation of the mature, cyclized fluorophore of GFP [22]. For this reason, the RFU was impacted by the level of the DO, which explained that the RFU/OD 600 remained stable after $24 \mathrm{~h}$. However, among this four different promoters, the cells expressing $g f p$ under regulation of $\mathrm{P}_{0169}$ promoter exhibited outstanding effect in the G. oxydans. The observation elucidated that the $\mathrm{P}_{0169}$ promoter was evidently recognized by G. oxydans and could reliably drive heterologous gene expression in G. oxydans.

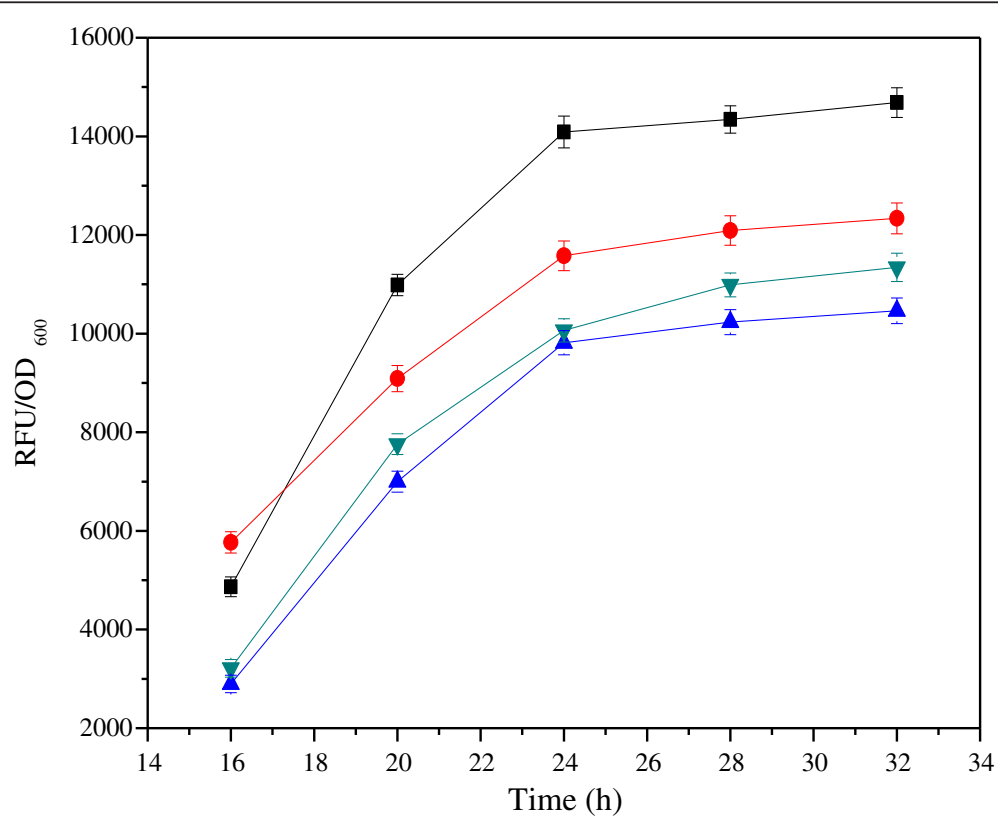

Fig. 2 Expression of green fluorescent protein in G. oxydans DSM2343 under the control of different promoter. The whole cell relative fluorescence unit (RFU) are the averages of three different experiments divided by the cell density at $600 \mathrm{~nm}$. $\mathbf{P _ { 0 1 6 9 }}$ promoter, $\mathrm{P}_{0264}$ promoter, $\triangle P_{0452}$ promoter, $\nabla P_{\text {tufB }}$ promoter 
Enzyme activity and relative transcriptional level of s/dAB overexpression strain

The glucose metabolism of the mutant G. oxydans ZJU2 strain showed the positive effect on the 5-KGA production [21], but it remained low productivity of 5-KGA. To boost the 5-KGA production, the $\operatorname{sldAB}$ gene was plasmid-based overexpressed in G. oxydans ZJU2 under the control of the selected $\mathrm{P}_{0169}$ promoter, generating $G$. oxydans ZJU3. The enzyme activity of SLDH of G. oxydans ZJU3 toward GA and the mRNA abundance of sldAB were investigated (Table 1). The SLDH activity was $2.55 \pm 0.04 \mathrm{U} / \mathrm{mg}$ protein, which was more 3 -fold higher than that of the reference strain. The $\operatorname{sld} A B$ expression data obtained were normalized to the transcriptional level of the 16S RNA. G. oxydans ZJU3 achieved the relative transcriptional level of $4.12 \pm 0.04$, which was 4-fold higher than those of the control. The results showed that the specific enzyme activities and transcription of the sldAB gene in G. oxydans could be markedly enhanced by $\operatorname{sld} A B$ overexpressed under the control of the selected $\mathrm{P}_{0169}$ promoter. In the literature [26], the stability and transcriptional level of the mRNA by adding poly $(\mathrm{A} / \mathrm{T})$ tails at the 3 '-UTR of the $\operatorname{sld} A B$ were discussed. It was revealed that an artificial poly $(\mathrm{A} / \mathrm{T})$ tail was proposed to slow down the mRNA degradation process in bacteria and the high $\operatorname{sld} A B$ expression levels were achieved. This well demonstrated the importance of the mRNA stability on the gene expression, which should be considered in our late study.

\section{Batch fermentation by sIdAB overexpression strain}

The batch fermentation by the recombinant G. oxydans ZJU3 strain was performed on a $15 \mathrm{~L}$ agitation tank under DOT rich condition. The results demonstrated that all tested strains had the similar trend of glucose consumption rate and cell growth (Fig. 3). The glucose was rapidly oxidized and exhausted at $30 \mathrm{~h}$, while about $130 \pm 1.76 \mathrm{~g} / \mathrm{L}$ of GA was accumulated over the same time frame. The reference strain, G. oxydans ZJU2, accumulated $82.48 \pm 1.10 \mathrm{~g} / \mathrm{L} 5$-KGA in the broth, but the residual GA was quite high at about $62.07 \pm 1.04 \mathrm{~g} / \mathrm{L}$ (Fig. 3a). In the fermentation process using recombinant G. oxydans ZJU3, $122.48 \pm 0.41 \mathrm{~g} / \mathrm{L}$ of 5 -KGA with the productivity of $1.92 \mathrm{~g} /(\mathrm{L} \cdot \mathrm{h})$ were obtained at $64 \mathrm{~h}$

Table 1 Enzyme activities and relative transcriptional levels of the membrane-bound SLDH in G. oxydans strains

\begin{tabular}{lcl}
\hline Strains & $\begin{array}{l}\text { Specific SLDH activity } \\
\text { (U/mg protein) }\end{array}$ & $\begin{array}{l}\text { Relative transcriptional } \\
\text { levels of sldAB gene }\end{array}$ \\
\hline G. oxydans ZJU2 & $0.75 \pm 0.02$ & $1.03 \pm 0.02$ \\
G. oxydans ZJU2/ & $0.74 \pm 0.01$ & $1.02 \pm 0.03$ \\
pBB5-P 0169 & & $4.12 \pm 0.04$ \\
$\begin{array}{l}\text { G. oxydans ZJU2/ } \\
\text { pBB5-P } P_{0169}-\text { SldAB }\end{array}$ & $2.55 \pm 0.04$ & \\
\hline
\end{tabular}

(Fig. 3b). Compared with the reference strain, the titer of 5 -KGA was increased $48.99 \%$ and the residual GA was $24.95 \pm 0.76 \mathrm{~g} / \mathrm{L}$, decreased $59.80 \%$.

However, the DCW of the tested strains was about $3.58 \pm 0.13 \mathrm{~g} / \mathrm{L}$, which was lower than other bacteria. In recent study, DNA microarray analysis and ${ }^{13} \mathrm{C}$ metabolic flux analysis $\left({ }^{13} \mathrm{C}-\mathrm{MFA}\right)$ are used to characterize the two growth phases of G. oxydans in the presence of glucose [25]. In the first growth phase, $90 \%$ of the glucose is oxidized by the mGDH to GA, accompanied by reasonable growth, high demand for oxygen and a low formation of $\mathrm{CO}_{2}$. The onset of phase II results in reduced biomass and demand for oxygen while the GA was oxidized in the periplasm to 5-KGA (Fig. 3). Thus, only a small percentage of the carbon source is taken up by cell, resulting in modest cell growth and poor cell yield. G. oxydans IFO3293 and G. oxydans $621 \mathrm{H}$ cells cultivated on glucose medium provids a cell yield of $0.09 \mathrm{~g} \mathrm{cdw} / \mathrm{g}$ glucose $[28,29]$. In comparison to these values, E. coli reaches a value of $0.49 \mathrm{~g} \mathrm{cdw} / g_{\text {glucose }}[30]$, and Bacillus subtilis reaches a yield of $0.32 \mathrm{~g} \mathrm{cdw} / \mathrm{g}$ glucose [31]. In phase I and II, the cytoplasmic sugar catabolism proceeded predominantly via the PPP, particularly in phase II [28].

During the glucose metabolism by $G$. oxydans, the mGDH and SLDH serve as the main enzymes, and PQQ is the cofactor. The PQQ supplementation experiments showed that the control strain G. oxydans ZJU2 was not significantly influenced by the exogenous PQQ (Fig. 3c), but the G. oxydans ZJU3 strain showed the respond to PQQ supplementation in a similar manner, achieving the highest 5-KGA production when the added PQQ was up to $500 \mu \mathrm{g} / \mathrm{L}$ (Fig. 3d). A total of $131.92 \pm 2.11 \mathrm{~g} / \mathrm{L}$ of 5-KGA was produced by G. oxydans ZJU3. These results indicated that the addition of PQQ could enhance the production of $5-\mathrm{KGA}$ in the SLDH overexpression strain, which was in agreement with a recent report that the overexpression of PQQ-dependent dehydrogenases could lead to imbalance between coenzyme PQQ level and the corresponding quinoproteins [24].

\section{Enhanced PQQ biosynthesis to improve 5-KGA production}

To further augment the 5-KGA production, the PQQ biosynthesis gene, $p q q A B C D E$, was engineered and the biomass growth, PQQ concentration and 5-KGA production were shown in Table 2. In G. oxydans ZJU4, overexpression of pqqABCDE gene cluster under the control of $\mathrm{P}_{0169}$ promoter led to the excretion of 674.82 $\pm 4.12 \mu \mathrm{g} / \mathrm{L}$ of PQQ into the supernatant, which was enhanced by $383.53 \%$ compared with that by the parent strain while the 5-KGA concentration was $131.76 \pm$ $1.89 \mathrm{~g} / \mathrm{L}$, an increase of $7.58 \%$. This also confirmed the results from the PQQ supplement experiment (Fig. 3) that the coenzyme PQQ was the key factor driving the 


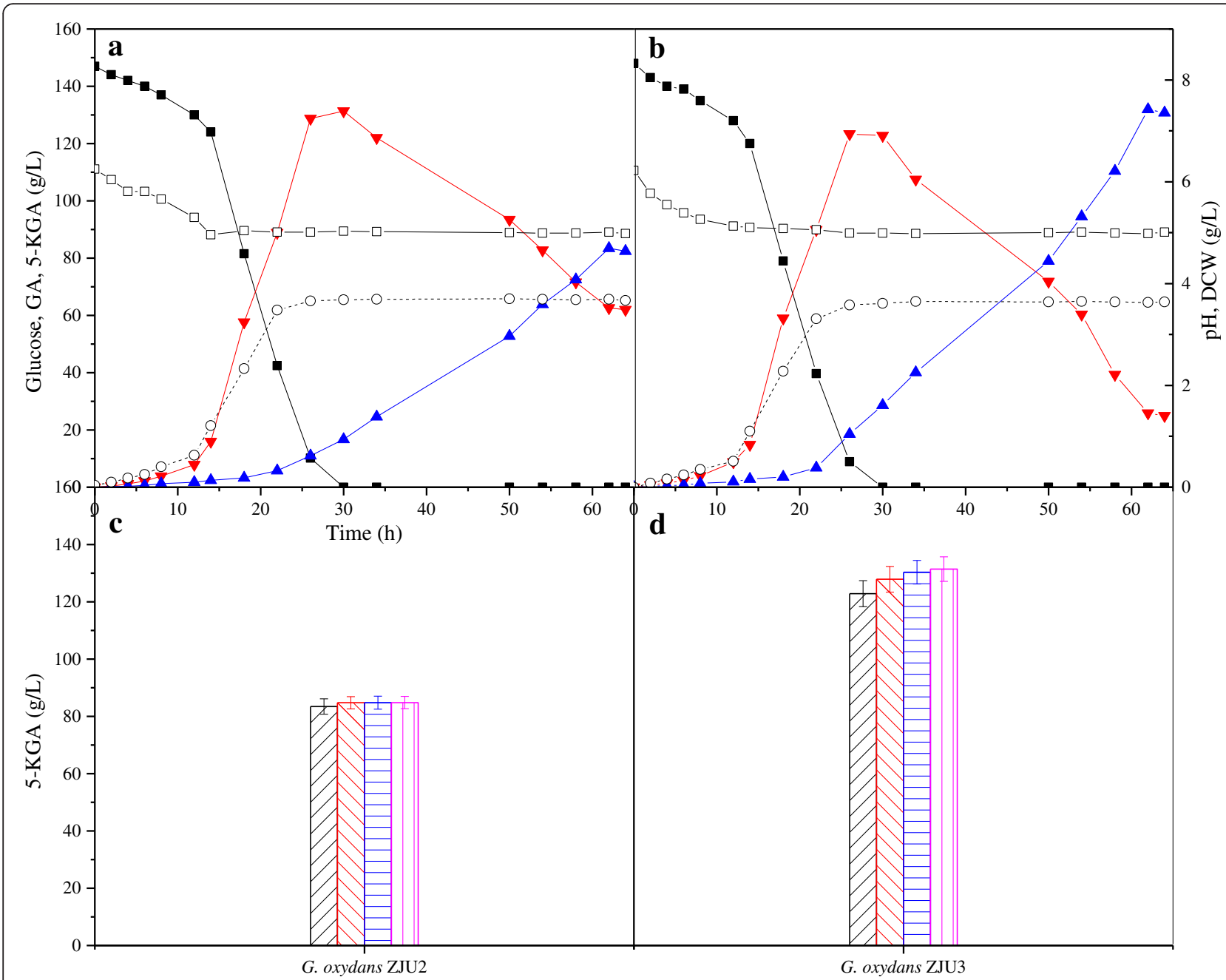

Fig. 3 Time-course of the oxidative fermentation in a 15-L fermentation tank and coenzyme PQQ complement study. a, c G. oxydans ZJU2, b, d

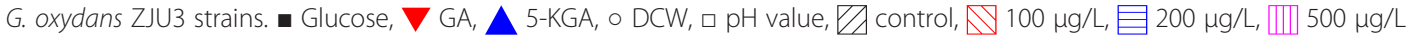

5-KGA production. In G. oxydans ZJU5, simultaneous expression of the PQQ gene cluster and an associated $t l d D$ gene produced $757.83 \pm 2.43 \mu \mathrm{g} / \mathrm{L}$ of $\mathrm{PQQ}$, which was increased by $12.30 \%$ compared with that from $G$. oxydans ZJU4. These results were consistent with the literature finding that the $t l d D$ gene was related to the PQQ biosynthesis [32]. The 5-KGA production by $G$. oxydans ZJU5 was $134.88 \pm 2.16 \mathrm{~g} / \mathrm{L}$. In addition, the cell growth of G. oxydans ZJU5 was comparable to that of
G. oxydans ZJU4. This finding implied that $t l d D$ gene expression did not affect the cell growth.

Overexpression of metabolic pathways involving redox reactions may lead to cofactor imbalances, thus impairing the yield of products. Cofactor engineering approaches are often adopted to compensate for imbalance of cofactors to improve product biosynthesis [33], for example, manipulating the availability of intracellular NADH [34] and NADPH [35]. In G. oxydans,

Table 2 Effects of overexpression pqaABCDE cluster and tIdD genes in G. oxydans strains

\begin{tabular}{llcc}
\hline Strains & $\begin{array}{l}\text { Max. DCW } \\
(\mathrm{g} / \mathrm{L})\end{array}$ & PQQ concentration $(\mu \mathrm{g} / \mathrm{L})$ & 5-KGA concentration $(\mathrm{g} / \mathrm{L})$ \\
\hline G. oxydans ZJU3 & $3.58 \pm 0.13$ & $139.56 \pm 1.87$ & $122.48 \pm 0.41$ \\
G. oxydans ZJU3/pUCpr & $3.39 \pm 0.09$ & $137.74 \pm 2.24$ & $118.89 \pm 1.28$ \\
G. oxydans ZJU3/pUCpr-T1 & $3.41 \pm 0.11$ & $674.82 \pm 4.12$ & $131.76 \pm 1.89$ \\
G. oxydans ZJU3/pUCpr-T2 & $3.40 \pm 0.08$ & $757.83 \pm 2.43$ & $134.88 \pm 2.16$ \\
\hline
\end{tabular}


quinoproteins and their cofactor PQQ can catalyze the oxidation of substrates by PQQ regulated electron transfer in the respiratory chain. However, the biosynthesis of quinoproteins and their cofactor PQQ are usually independent [24]. Therefore, the PQQ gene cluster was overexpressed in Gluconobacter oxydans WSH-003 [23] and Ketogulonigenium vulgare [24], which demonstrated to improve 2-keto-L-gulonic acid (2-KLG) production by cofactor engineering. These advance significantly facilitated the development of the efficient strains to produce 5-KGA.

Notably, it was reported that disruption of $t l d D$ gene in G. oxydans led to a drop of PQQ excretion below the detection limit and a decrease in cell growth, indicating that the related $t l d D$ gene was essential for PQQ biosynthesis [32]. The TldD protein of G. oxydans $621 \mathrm{H}$, related to the $E$. coli TldD, is a peptidase involved in processing of small peptides. In other PQQ-producing bacteria, the peptidase-like protein PqqF is required for PQQ synthesis and has a similar function as the TldD in G. oxydans [32]. Therefore, our study demonstrated that overexpression of the $t l d D$ gene could increase PQQ level by $12.30 \%$ in G. oxydans ZJU5 compared with that of G. oxydans ZJU4 (Table 2). This cofactor engineering was adopted to compensate the shortage of cofactors in the PQQ-dependent SLDH overexpression strain and to improve the 5-KGA production.

\section{The engineering of the respiratory chain}

In an earlier study, the cytochrome $b o_{3}$ oxidase (cyoBACD, GOX1911-1914) was found to be the main component for proton extrusion via the respiratory chain in G. oxydans $621 \mathrm{H}$ [25]. To enhance the respiratory chain activity and the 5-KGA production, the cytochrome $b_{3}$ oxidase was engineered. The cyoBACD genes were fused into the $\mathrm{PQQ}$ overexpression plasmid (pUCpr-T1 and pUCpr-T2) under the $\mathrm{P}_{0169}$ promoter control, generating pUCpr-T3 and pUCpr-T4. The corresponding plasmids were electrotransferred into G. oxydans ZJU3, resulting in G. oxydans ZJU6 and G. oxydans ZJU7, respectively.

The batch fermentations of G. oxydans ZJU4, G. oxydans ZJU5, G. oxydans ZJU6, and G. oxydans ZJU7, under an excess of oxygen, showed that all recombinant G. oxydans strains reached their maximal OTR. The time points of maximal OTR correlated with the time points at which about $60 \%$ glucose had been predominantly oxidized to GA in the periplasm (Fig. 4). G. oxydans ZJU4 and G. oxydans ZJU5 reached their maximal OTR of $26.52 \mathrm{mmol} / \mathrm{L} \cdot \mathrm{h}$ and $29.85 \mathrm{mmol} / \mathrm{L} \cdot \mathrm{h}$, respectively at $19 \mathrm{~h}$. After complete consumption of glucose, the OTR decreased to 1.5 to $1.8 \mathrm{mmol} / \mathrm{L} \cdot \mathrm{h}$. The specific maximal $\mathrm{CO}_{2}$ production rate (CTR) of both strains was $7.5 \mathrm{mmol} / \mathrm{L} \cdot \mathrm{h}$ at $32 \mathrm{~h}$, then it began to decrease (Fig. 4a, b). The CTR decreased below $5.0 \mathrm{mmol} / \mathrm{L} \cdot \mathrm{h}$ at $57 \mathrm{~h}$ for

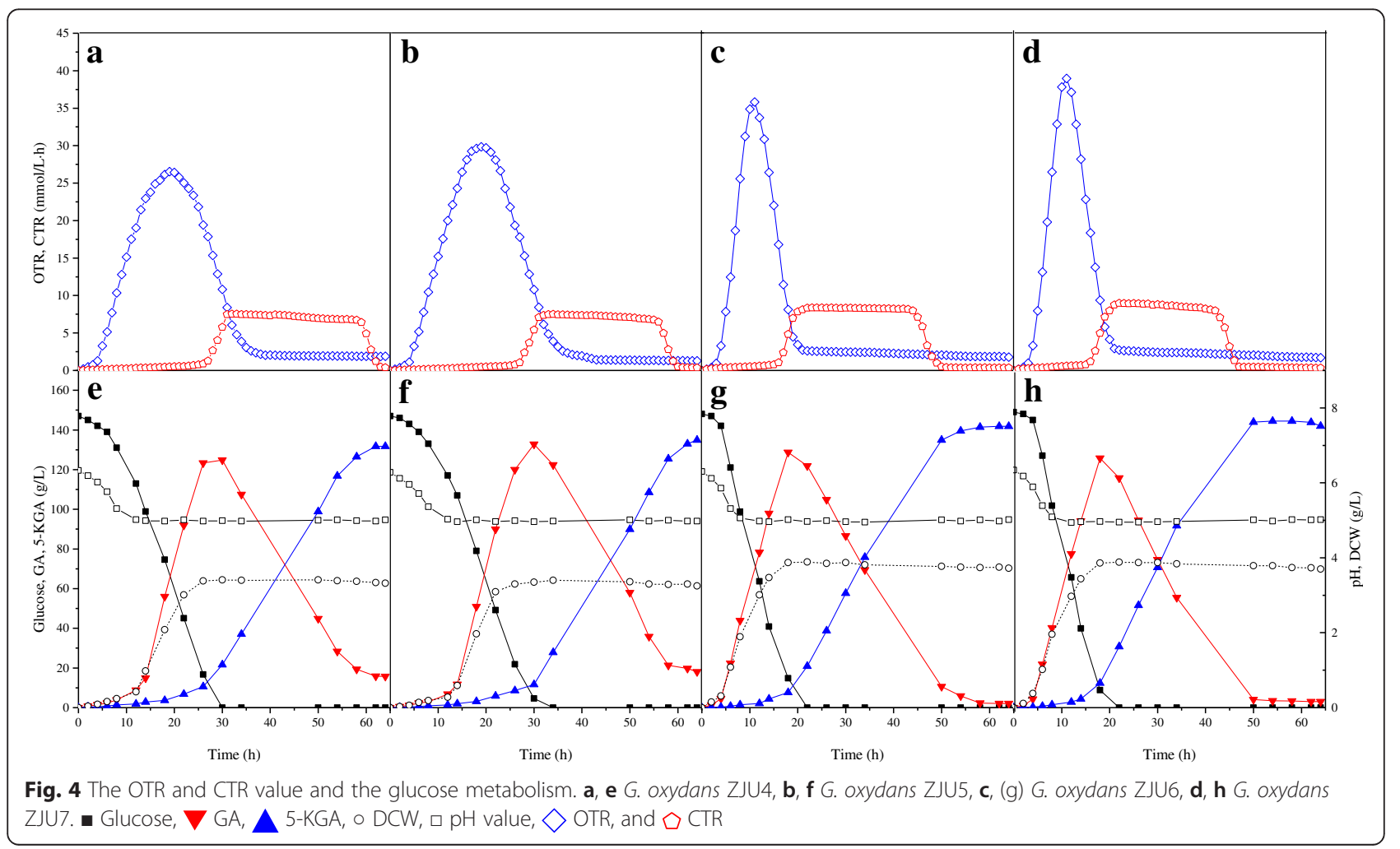


the G. oxydans ZJU5 strain, but it decreased below this level at $60 \mathrm{~h}$ for G. oxydans ZJU4. This meant that the $t l d D$ gene overexpression could increase the PQQ biosynthesis and the oxidation rate of SLDH. The situations of G. oxydans ZJU6 and G. oxydans ZJU7 were remarkable different with those of G. oxydans ZJU4 and G. oxydans ZJU5, where $141.86 \pm 2.89 \mathrm{~g} / \mathrm{L}$ and $144.52 \pm 2.94 \mathrm{~g} /$ L 5-KGA was accumulated, respectively. The glucose oxidation rate was accelerated, and glucose was exhausted at $20 \mathrm{~h}$. The maximal OTR of $35.83 \mathrm{mmol} / \mathrm{L}$. $\mathrm{h}$ and $38.97 \mathrm{mmol} / \mathrm{L} \cdot \mathrm{h}$ were achieved at $11 \mathrm{~h}$, respectively. After $22 \mathrm{~h}$, the CTRs of ZJU6 and ZJU7 reached the maximal values of $8.38 \mathrm{mmol} / \mathrm{L} \cdot \mathrm{h}$ and $8.98 \mathrm{mmol} /$ $\mathrm{L} \cdot \mathrm{h}$, respectively. The CTR of G. oxydans ZJU7 decreased to $0.5 \mathrm{mmol} / \mathrm{L} \cdot \mathrm{h}$ at $47 \mathrm{~h}$, which was $13 \mathrm{~h}$ and 3 h short than those of G. oxydans ZJU5 and G. oxydans ZJU6, respectively (Fig. 4c, d). This indicated that the oxidation of GA to 5-KGA by G. oxydans ZJU7 had completely finished at $47 \mathrm{~h}$.

Using the constructed G. oxydans strains, the $\mathrm{H}^{+} / \mathrm{O}$ ratio and terminal ubiquinol $b o_{3}$ oxidase activity were also measured when the cells were in the logarithmic growth phase (DCW of 1.5). The results were shown in Table 3. The average $\mathrm{H}^{+} / \mathrm{O}$ ratio and terminal ubiquinol oxidase activity of the control strain G. oxydans ZJU3 were $1.24 \pm 0.11$ and $0.31 \pm 0.04 \mu \mathrm{mol} / \mathrm{min} \cdot \mathrm{mg}$, respectively. The G. oxydans ZJU4 and G. oxydans ZJU5 had an $\mathrm{H}^{+} / \mathrm{O}$ ratio and terminal ubiquinol oxidase activity comparable to those of the control strain, implying the mutant growth was not impaired under conditions of PQQ cluster overexpression. However, the recombinant $G$. oxydans ZJU6 and G. oxydans ZJU7 showed a $64 \%$ increase of the $\mathrm{H}^{+} / \mathrm{O}$ ratio $(1.95 \pm 0.23$ and $2.01 \pm 0.16)$ and 1.5 -fold of the ubiquinol oxidase activity $(0.78 \pm$ $0.05 \mu \mathrm{mol} / \mathrm{min} \cdot \mathrm{mg}$ and $0.80 \pm 0.06 \mu \mathrm{mol} / \mathrm{min} \cdot \mathrm{mg}$ ) compared with the control strain, respectively. A total of $141.86 \pm 2.89 \mathrm{~g} / \mathrm{L}$ and $144.52 \pm 2.94 \mathrm{~g} / \mathrm{L} 5$-KGA was accumulated by G. oxydans ZJU6 and G. oxydans ZJU7, respectively. This indicated the expression of ubiquinol $b o_{3}$ oxidase could enhance respiratory proton translocation and increase the 5-KGA production in G. oxydans.

G. oxydans possesses a branched respiratory chain consisting of two terminal ubiquinol oxidases, cytochrome $b_{3}$ oxidase and cytochrome $b d$ oxidase (cydAB, GOX0278-0279) (Fig. 1). The genome sequence also revealed genes for a cytochrome $b c_{1}$ complex ( $\operatorname{rr} A B C$, GOX0565-0567) and a soluble cytochrome $c$ (GOX0258) [10]. The absence of cytochrome $b d$ oxidase did not affect the cell growth or proton extrusion via the respiratory chain, whereas absence of the genes encoding cytochrome $\mathrm{bo}_{3}$ oxidase caused a severe growth defect [25]. Plasmidbased overproduction of cytochrome $b o_{3}$ oxidase under the $\mathrm{P}_{0169}$ promoter control increased the respirationdriven proton extrusion by $66.7 \%$ in G. oxydans ZJU6 and G. oxydans ZJU7, compared with the control strains (Table 3). The increase in the $\mathrm{H}^{+} / \mathrm{O}$ ratio might be owing to the presence of more $b o_{3}$ quinol oxidase and its proposed high oxygen affinity, which should favor oxygen reduction under the experimental conditions of an oxygen pulse [25]. The $\mathrm{H}^{+} / \mathrm{O}$ ratio for the reference strain, G. oxydans ZJU3, was measured as $1.21 \pm 0.11$. In the literature, $\mathrm{H}^{+} / \mathrm{O}$ ratios reported for $E$. coli vary between 3.4 and 4.5 $[36,37]$, which was more than 2-fold higher than that of the G. oxydans ZJU3 strain. A major difference of the respiratory chain between the two species is the lack of the multisubunit proton-pumping $\mathrm{NADH}$ dehydrogenase I (NDH-I) in the G. oxydans [10, 25]. However, NDH-I is preferentially synthesized during anaerobic growth in the presence of alternate electron acceptors [38]. Therefore, what extent NDH-I contributes to the $\mathrm{H}$ ${ }^{+} / \mathrm{O}$ ratio is unclear. As the $b d$ oxidase was not relevant for proton translocation, an $\mathrm{H}^{+} / \mathrm{O}$ ration of 4 might be assumed for G. oxydans [39]. However, our results were much lower than a value of 4 . Richhardt explained that cytochrome $b_{3}$ oxidase might not function as a primary proton pump but as a $\mathrm{Na}^{+}$ pump and the respiratory chain could involve a reverse electron transfer coupled to an influx of protons [25].

Interestingly, an increased $15.48 \%$ cell yield was observed when the $b o_{3}$ oxidase gene was overexpressed (Fig. $4 \mathrm{~g}, \mathrm{~h}$ ). The possibility of an increased $b o_{3}$ oxidase level in G. oxydans could cause a shift of the electron flux from the non-proton pumping $b d$ oxidase to the proton pumping $b_{3}$ oxidase [25]. Another explanation for the increased cell growth is the assumption that the

Table $3 \mathrm{H}^{+} / \mathrm{O}$ ratio and ubiquinol oxidase activity of recombinant $\mathrm{G}$. oxydans strains

\begin{tabular}{llcc}
\hline Strains & $\begin{array}{l}\mathrm{H}^{+} / \mathrm{O} \text { ratio }^{a} \\
(\text { No. of experiments) }\end{array}$ & $\begin{array}{l}\text { Ubiquinol oxidase activity } \\
(\mu \mathrm{mol} / \mathrm{min} \cdot \mathrm{mg})\end{array}$ & $\begin{array}{l}5-\mathrm{KGA} \\
\text { production } \\
(\mathrm{g} / \mathrm{L})\end{array}$ \\
\hline G. oxydans ZJU3 & $1.21 \pm 0.11(8)$ & $0.31 \pm 0.04$ & $122.48 \pm 0.41$ \\
G. oxydans ZJU4 & $1.19 \pm 0.10(8)$ & $0.32 \pm 0.05$ & $131.76 \pm 1.89$ \\
G. oxydans ZJU5 & $1.20 \pm 0.11(8)$ & $0.30 \pm 0.11$ & $134.88 \pm 2.16$ \\
G. oxydans ZJU6 & $1.95 \pm 0.23(8)$ & $0.78 \pm 0.05$ & $141.86 \pm 2.89$ \\
G. oxydans ZJU7 & $2.01 \pm 0.16(8)$ & $0.80 \pm 0.06$ & $144.52 \pm 2.94$ \\
\hline
\end{tabular}

$a_{\text {the }} \mathrm{H}^{+} / \mathrm{O}$ measured by the oxygen pulse method 
activity of the $b o_{3}$ oxidase is limited and can be increased by its overproduction. This was confirmed in the experiments that the ubiquinol oxidase activity increased 2.5-fold (Table 3) and the OTR enhanced $9.12 \mathrm{mmol} / \mathrm{L} \cdot \mathrm{h}$ (Fig. 4) by overexpressed the cyoBACD genes, indicating that cytochrome $b o_{3}$ quinol oxidase played the positive role in the cell growth and substrate oxidation. Recently, a limitation of oxygen consumption by the activity of the terminal oxidase was reported after overexpressing the membrane-bound glucose dehydrogenase (mGDH, GOX0265) [40]. This implied that the activity of $b o_{3}$ quinol oxidase might be high enough to satisfy the increased capacity for oxygen reduction.

\section{Process optimization and fed-batch fermentation}

The constructed G. oxydans ZJU7 showed good potential for 5-KGA production. To fulfill the requirement of industrial production of 5-KGA, the fermentation process was optimized, including the two-stage $\mathrm{pH}$ control, DO control and glucose feed. As shown in Fig. 5a, the glucose was oxidized faster and exhausted at $14 \mathrm{~h}$ when the $\mathrm{pH}$ was controlled at 5.5. This result was consistent with the previous results where a $\mathrm{pH}$ of 5.5 was suitable for the activity of membrane-bound glucose dehydrogenase [41]. However, a pH of 4.5 was more suitable for synthesis of 5-KGA by SLDH. In the early study, the $\mathrm{pH}$ of the culture medium was an important factor
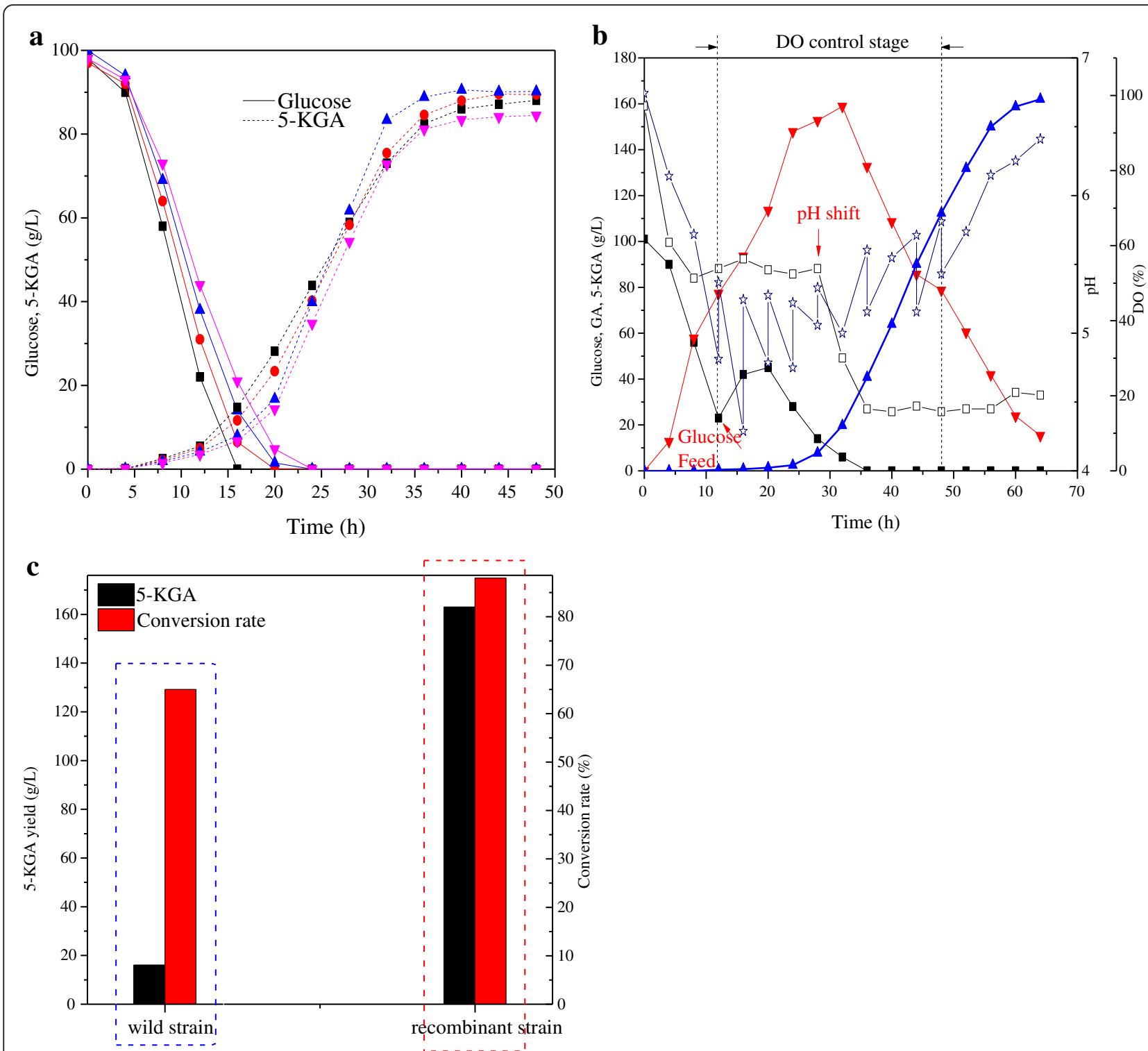

Fig. 5 a Effect of $\mathrm{pH}$ on the glucose consumption and 5-KGA production by G. oxydans ZJU7. $\mathbf{p H}$ 5.5, $\mathrm{pH}$ 5.0, $\mathbf{A} \mathrm{pH}$ 4.5, $\mathbf{\nabla} \mathrm{pH}$ 4.0. b The

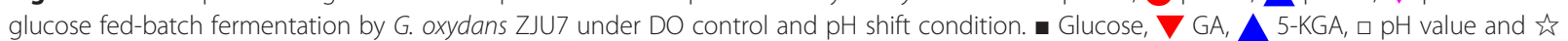
DO. c The 5-KGA production and conversion rate between G. oxydans ZJU7 and wild-type strains. black-bar, 5-KGA, red-bar, conversion rate 
for selective production of 5-KGA by G. suboxydans IFO 12528 , in which an $87 \%$ glucose conversion rate could be achieved by controlling the medium $\mathrm{pH}$ in a range of 3.5-4.0 [20]. According to the experimental results, we have established a two-stage $\mathrm{pH}$ control strategy, whereas the $\mathrm{pH}$ is controlled as 5.5 in the first stage to let the glucose oxidation and cell growth, then it is shifted to 4.5, facilitating 5-KGA formation.

In its natural habitat, G. oxydans is likely subjected to low-oxygen stress conditions because of the rapid oxygen consumption as a result of its own metabolism. The OTR and CTR were previously investigated during the 5-KGA production, in which the high OTR was observed when the glucose was oxidized to GA in the periplasm (Fig. 4a, b, c, d). It was reported that oxygen limitation could cause expression changes of 486 genes, representing $20 \%$ of the chromosomal genes [42]. Therefore, during this stage, it must ensure the adequate DOT above $20 \%$ by increasing the agitation speed. The onset of 5-KGA formation decreased the demand for DOT but increased the CTR (Fig. 4a, b, c, d). Hence, to improve the cost performance of the industrial production of 5-KGA, DOT was continuously controlled by adjusting the agitation speed according to OTR and CTR.

Additionally, to achieve the hyper-production of 5-KGA by the recombinant $G$. oxydans ZJU7 strain, the glucose fed-batch fermentation was carried out under the DOT and $\mathrm{pH}$ control. A glucose feed of about $1400 \mathrm{~g}$ was started at $12 \mathrm{~h}$ when the glucose concentration was below $40 \mathrm{~g} / \mathrm{L}$ and was used to maintain the glucose at $40 \sim 50 \mathrm{~g} / \mathrm{L}$ (Fig. $5 \mathrm{~b}$ ). The GA quickly accumulated during this stage. When the glucose concentration dropped to $14 \mathrm{~g} / \mathrm{L}$ at $28 \mathrm{~h}$, the 5KGA began to quickly be formed and the $\mathrm{pH}$ shifted from 5.5 to 4.5. Concurrently, the DOT was controlled above $20 \%$. Using glucose fed-batch fermentation, DOT control, and a $\mathrm{pH}$ shift strategy, the 5-KGA titer was increased to $162 \pm 2.12 \mathrm{~g} / \mathrm{L}$ with the $2.53 \mathrm{~g} /(\mathrm{L} \cdot \mathrm{h})$ productivity by the recombinant G. oxydans ZJU7 strain, which was increased by 10-fold compared to the wild-type strain (Fig. 5c). This indicated that the PQQ overexpression and respiratory chain modification could efficiently enhance 5-KGA accumulation. Furthermore, the problem of residual GA was well solved, and the final concentration of GA was reduced to $15.38 \mathrm{~g} / \mathrm{L}$, which should decrease the separation difficulty. These results illustrated that the supplement of co-enzyme to the membrane-bound dehydrogenases was increased by overexpression of the PQQ cluster genes. The efficiency of electron transfer to $\mathrm{O}_{2}$ was enhanced by overexpression of the genes for the $b o_{3}$ oxidase, which increased the activity of respiratory chain.

\section{Conclusion}

Bacteria of the genus Gluconobacter exhibit so-called oxidative fermentation, or incomplete oxidation, a highly unusual metabolic feature that has been exploited industrially for decades in the production of vitamin $\mathrm{C}$, GA and dihydroxyacetone [43]. In this study, the role of the combinatorial metabolic engineering of the industrial $G$. oxydans for the boosting of 5-KGA accumulation was investigated. In summary, the $\operatorname{sld} A B$ was overexpressed under the selected $\mathrm{P}_{0169}$ promoter. In addition, the PQQ gene cluster and terminal ubiquinol $b o_{3}$ oxidase were fused overexpression to strengthen the glucose oxidation. Under the optimized culture conditions of the fedbatch process, the combinatorial approaches collectively increased the 5-KGA titer 10-fold, reached $162 \pm 2.12 \mathrm{~g} /$ L. The results showed great potential for optimizing the current producer strain of G. oxydans used in industrial biotechnology, which presents the first report of 5-KGA production by combinatorial metabolic engineering approaches in G. oxydans. We envision that these approaches could provide framework for devising engineering strategies to improve the production of biochemicals in G. oxydans. Nevertheless, some issues are still worth further study, for example, how many copies of $p q q$ cluster and $b o_{3}$ oxidase genes overexpression can be matched the quinoproteins requirements, especially in the quinoproteins overexpression strains. The genome sequence has revealed that the TCA cycle is incomplete as genes for succinate dehydrogenase and succinyl CoA synthetase were absent [10]. To develop more robust strains, the strategy involving direct repair of this defective metabolic pathway by genomic integration of heterologous genes should be investigated, while considering the G. oxydans as a broadly applicable host for oxidative industrial bioconversions.

\section{Methods}

\section{Bacterial strains, plasmids, and media}

The bacterial strains, and plasmids used in this study are listed in Table 4. Escherichia coli strains were cultivated in Luria-Bertani (LB) medium at $37^{\circ} \mathrm{C}$. The $50 \mu \mathrm{g} / \mathrm{mL}$ gentamicin or $100 \mu \mathrm{g} / \mathrm{mL}$ ampicillin were used whenever required. Agar (1.5\%) was added to obtain solid media. Gluconobacter oxydans DSM2343 strains were cultivated on mannitol medium (MP) containing $5 \mathrm{~g} / \mathrm{L}$ yeast extract, $3 \mathrm{~g} / \mathrm{L}$ peptone, and $25 \mathrm{~g} / \mathrm{L}$ mannitol at $30{ }^{\circ} \mathrm{C}$. For G. oxydans possesses a natural resistance against cefoxitin, thus, as a precaution to prevent bacterial contamination, $50 \mu \mathrm{g} / \mathrm{mL}$ cefoxitin was added.

\section{Construction of shuttle vector}

A shuttle vector pUCpr, compatible to the broad-hostplasmid pBBR1MCS5, was constructed. The 2446-bp par-rep gene fragment of cryptic plasmid pGOX3 from G. oxydans DSM2343 was amplified with primers pr_PstI_F / pr_SalI_R (Table 5). The sequenced PCR 
Table 4 Bacterial strains and plasmids used in this work

\begin{tabular}{|c|c|c|}
\hline & Properties & Source \\
\hline \multicolumn{3}{|l|}{ Strains } \\
\hline E. coli DH5a & $\begin{array}{l}\text { F, endA1, hsdR17 (rk-mk-),supE44, thi1, recA1, gyrA, (Nalr), } \\
\text { relA1, D(lacZYAargF), U169, and F80lacZDM15 }\end{array}$ & Invitrogen \\
\hline G. oxydans DSM2343 & Wild-type, $\mathrm{Cef}^{R}$ & DSMZ $Z^{\mathrm{a}}$ \\
\hline G. oxydans ZJU2 & $\begin{array}{l}\text { Gluconate 2-dehydrogenase and pyruvate decarboxylase } \\
\text { deletion strain derived from G. oxydans DSM2343, Cef }{ }^{R}\end{array}$ & [21] \\
\hline G. oxydans ZJU3 & G. oxydans ZJU2 harboring pBB5-P $\mathrm{P}_{0169}-{ }^{-} / \mathrm{d} A B, \mathrm{Cef}^{\mathrm{R}}, \mathrm{Gm}^{\mathrm{R}}$ & This work \\
\hline G. oxydans ZJU4 & G. oxydans ZJU3 harboring pUCpr-T1, $\mathrm{Cef}^{R}, \mathrm{Gm}^{\mathrm{R}}, \mathrm{Amp}^{\mathrm{R}}$ & This work \\
\hline G. oxydans ZJU5 & G. oxydans ZJU3 harboring pUCpr-T2, Cef ${ }^{R}, \mathrm{Gm}^{\mathrm{R}}, \mathrm{Amp}^{\mathrm{R}}$ & This work \\
\hline G. oxydans ZJU6 & G. oxydans ZJU3 harboring pUCpr-T3, Cef ${ }^{R}, G^{R}, A m p^{R}$ & This work \\
\hline G. oxydans ZJU7 & G. oxydans ZJU3 harboring pUCpr-T4, Cef ${ }^{R}, \mathrm{Gm}^{\mathrm{R}}, \mathrm{Amp}^{\mathrm{R}}$ & This work \\
\hline \multicolumn{3}{|l|}{ Plasmids } \\
\hline pUC19 & Cloning vector, ColE1 ori, $\mathrm{Amp}^{R}$ & Invitrogen \\
\hline pET28 (a)-GFP & gpf gene expressed vector, $\mathrm{Km}^{\mathrm{R}}$ & $\begin{array}{l}\text { Laboratory } \\
\text { preservation }\end{array}$ \\
\hline pBBR1MCS-5 & Broad-host-range (bhr) expression vector, $\mathrm{Gm}^{\mathrm{R}}$ & [45] \\
\hline pBB5-P $P_{\text {tufB }}$ & Insert $P_{\text {tufB }}$ promoter vector derived from pBBR1MCS-5, Gm & This work \\
\hline pBB5- $P_{0264}$ & Insert $\mathrm{P}_{0264}$ promoter vector derived from pBBR1MCS-5, Gm ${ }^{R}$ & This work \\
\hline pBB5- $P_{0452}$ & Insert $P_{0452}$ promoter vector derived from pBBR1MCS-5, Gm ${ }^{R}$ & This work \\
\hline pBB5- $P_{0169}$ & Insert $\mathrm{P}_{0169}$ promoter vector derived from pBBR1MCS-5, Gm ${ }^{R}$ & This work \\
\hline pBB5-P $0169-5 / d A B$ & $\begin{array}{l}\text { sldAB gene overexpression vector derived from pBBR1MCS-5, } \\
\text { inserted } \mathrm{P}_{0169} \text { promoter, } \mathrm{Gm}^{R}\end{array}$ & This work \\
\hline pUCpr & $\begin{array}{l}\text { Constructed expression vector derived from pUC19, } \\
\text { par-rep, Amp }{ }^{R}\end{array}$ & This work \\
\hline pUCpr-T1 & pUCpr-P ${ }_{0169}-p q q A B C D E$ vector derived from $p U C p r, A m p^{R}$ & This work \\
\hline pUCpr-T2 & pUCpr-P ${ }_{0169}-p q q A B C D E-t / d D$ vector derived from $p U C p r, A m p^{R}$ & This work \\
\hline pUCpr-T3 & $\begin{array}{l}\text { pUCpr-P } 0169-p q q A B C D E-P_{0169}-C y o B A C D \text { vector derived from } \\
\text { pUCpr, Amp }\end{array}$ & This work \\
\hline pUCpr-T4 & $\begin{array}{l}\text { pUCpr- } P_{0169}-p q q A B C D E-t l d D-P_{0169}-C y 0 B A C D \text { vector derived } \\
\text { from pUCpr, Amp }{ }^{R}\end{array}$ & This work \\
\hline
\end{tabular}

product was digested and inserted into the PstI/SalI site of the pUC19, resulting in pUCpr [44].

\section{Promoter selection}

Four different promoters from G. oxydans DSM2343 were carefully selected. A putative promoter sequence, $\mathrm{P}_{0169}$ [22], the promoter of elongation factor $T u, \mathrm{P}_{\text {tufB }}$ [26], and ribosomal proteins L35 and L13, $\mathrm{P}_{0264}$ and $\mathrm{P}_{0452}$ [27], were amplified by PCR with primers as listed in Table 5 . The resulting DNA fragments $\mathrm{P}_{\text {tufB }}, \mathrm{P}_{0264}, \mathrm{P}_{0452}$ and $\mathrm{P}_{0169}$ were digested with restriction enzymes $S a c I$ and $X b a \mathrm{I}$, then were ligated into pBBR1MCS-5 [45], generated the vector pBB5- $\mathrm{P}_{\text {tufB }}, \mathrm{pBB} 5-\mathrm{P}_{0264}, \mathrm{pBB} 5-\mathrm{P}_{0452}$ and $\mathrm{pBB} 5-\mathrm{P}_{0169}$, respectively. The report gene $g f p$ was amplified from the cloning vector pET28 (a)-GFP. The resulting product was digested with $\mathrm{XbaI}$ and HindIII, and then cloned into the XbaI and HindIII site of pBB5- $\mathrm{P}_{\text {tufB }}, \mathrm{pBB} 5-\mathrm{P}_{0264}, \mathrm{pBB} 5-$
$\mathrm{P}_{0452}$ and $\mathrm{pBB} 5-\mathrm{P}_{0169}$ to generate the corresponding promoter strength reporter plasmids.

The reporter plasmids were first transformed into $E$. coli $\mathrm{DH} 5 \alpha$, analyzed for the correct insert by DNA sequencing and then transformed into G. oxydans DSM2343 by electroporation $(2000 \mathrm{~V}, 200 \Omega$ and $25 \mu \mathrm{F})$ in a 2-mm cuvette using a Gene Pulser II (Bio-Rad, München, Germany) as described previously [46]. The transformants were selected by cefoxitin and gentamicin. The whole cell fluorescence intensity (RFU/OD, the relative fluorescence unit divided by the corresponding cell density) was measured [22]. Cells were harvested and washed twice with KPB buffer ( $\mathrm{pH} 7.0$ ), and then photographed by using a confocal laser scanning microscope. The cell density was measured by the absorbance at $600 \mathrm{~nm}$ using the spectrophotometer (UVmini-1240, SHIMADZU'), which determined the strengths of the different promoters. 
Table 5 The oligonucleotides primers used in this work

\begin{tabular}{|c|c|c|}
\hline Primer & Sequence $\left(5^{\prime} \rightarrow 3^{\prime}\right)$ & Usage \\
\hline pr_Pstl_F & AACTGCAGgtttatcggccgttgaatat & \multirow[t]{2}{*}{ Amplify the par-rep gene } \\
\hline pr_Sall_R & ACGCGTCGACggtgtttaaacagtgttacggt & \\
\hline 0169_Sacl_F & ATAGAGCTCtgaaagcggctggcgcgt & \multirow{2}{*}{$\begin{array}{l}\text { Amplify the 5'-UTR of GOX0169 } \\
\text { promoter }\end{array}$} \\
\hline 0169_Xbal_R & GCTCTAGAgcggaaggcgttataccctga & \\
\hline 0264_Sacl_F & ATAGAGCTCgttgcgcctgaatgagagg & \multirow{2}{*}{$\begin{array}{l}\text { Amplify the 5'-UTR of GOX0264 } \\
\text { promoter }\end{array}$} \\
\hline 0264_Xbal_R & GCTCTAGAttcggtctccctcgecgtaa & \\
\hline 0452_Sacl_F & ATAGAGCTCggcttcgtggtgaacgcc & \multirow{2}{*}{$\begin{array}{l}\text { Amplify the } 5^{\prime} \text {-UTR of GOX0452 } \\
\text { promoter }\end{array}$} \\
\hline 0452_Xbal_R & GCTCTAGAtagtgacattccagcttggg & \\
\hline tufB_Sacl_F & ATAGAGCTCcgatggtaagaaatccactgc & \multirow[t]{2}{*}{ Amplify the tufB promoter } \\
\hline tufB_Xbal_R & ATATCTAGAccaaaaccccgctccacc & \\
\hline GFP_Xbal_F & ATATCTAGAatggtgagcaaggge & \multirow[t]{2}{*}{ Amplify the gfp reported gene } \\
\hline GFP_HindIII_R & CCCAAGCTTctacttgtacagctc & \\
\hline SLDH_Xbal_F & GCTCTAGAggactttcagttctggaggctttcacca & \multirow[t]{2}{*}{ Amplify the $s / d A B$ gene } \\
\hline SLDH_ECORI_R & CGGAATTCtcccacccgaaaaatggaaaaaacg & \\
\hline ADD_0169_F & acactgtttaaacaccgtgaaagcggctggcgc & \multirow[t]{8}{*}{ Amplify the fuse fragments } \\
\hline pQQ_Fuse0169_R & acatccgcgcggaaggcgttatac & \\
\hline pQQ_Fuse0169_F & ccttccgcgcggatgttcagg & \\
\hline tldD_FusepQQ_R & ccggctagaagatggectctc & \\
\hline tldD_FusepQQ_F & gccatcttctagccggtctgttc & \\
\hline 0169_FusetldD_R & ctttcaggatcttcttcatg & \\
\hline 0169_FusetldD_F & tcgcgactgaaagcggctggc & \\
\hline ADD_0169_R & cggtacccggggatcctgcggaaggcgttatac & \\
\hline cyoBACD_Xbal_F & CGATTCTAGAactactgcaagccggaacgg & \multirow{2}{*}{$\begin{array}{l}\text { Amplify the terminal cytochrome } \\
b_{3} \text { oxidase }\end{array}$} \\
\hline cyoBACD_Sacl_R & ACTGGAGCTCaagggctggcaggatttctc & \\
\hline RT16S_F & gcggttgttacagtcagatg & - \\
\hline RT16S_R & gcctcagcgtcagtatcg & - \\
\hline RTsldh_F & atcatgccgaccaagcgtggc & - \\
\hline RTsldh_R & cgtcggcgaacgcggatcg & - \\
\hline
\end{tabular}

${ }^{a}$ The capital and underlined sequences indicate the restriction enzyme sites

\section{Overexpression of sldAB gene in G. oxydans ZJU2}

Based on the bioinformatics analysis of G. oxydans $621 \mathrm{H}$ genome sequence [10], SLDH_XbaI_F / SLDH_EcoRI_R primers were designed and the open reading frames (ORFs) of SLDH (sldAB, GOX0854-0855) was PCR-amplified with the primers. The genomic DNA of G. oxydans DSM 2343 was used as a template. The sequenced amplicon was digested with the restriction endonucleases $X b a \mathrm{I}$ and EcoRI and cloned into pBB5$\mathrm{P}_{0169}$ vector restricted with the same enzymes, resulting in plasmids $\mathrm{pBB} 5-\mathrm{P}_{0169}-$ sldAB. This plasmid and as a control pBB5- $\mathrm{P}_{0169}$ vector were transferred into the desired G. oxydans ZJU2 strain by electroporation and were selected for a gentamycin-resistant phenotype. The correct strain G. oxydans ZJU2/pBB5- $\mathrm{P}_{0169}-$ sldAB was named G. oxydans ZJU3.

\section{Co-expression of the PQQ biosynthesis genes and the terminal ubiquinol cytochrome $b_{3}$ oxidase genes in $G$. oxydans ZJU3}

In the oxidation process by the membrane-bound SLDH, the PQQ serves as prosthetic groups $[10,15,16]$, which transfer electrons to the respiratory chain [10]. To enhance the 5-KGA production, the genes encoding the cofactor PQQ and the terminal ubiquinol cytochrome $b o_{3}$ oxidase of the respiratory chain were reinforced. To fulfill the experiments, the PQQ gene cluster (GOX0983-0987) and the related $t l d D$ gene (GOX1104) were cloned and the generated plasmids pUCpr-T1 and pUCpr-T2. The constructed plasmids were transferred into G. oxydans ZJU3, resulting the recombinant strains G. oxydans ZJU4 and G. oxydans ZJU5, respectively. The PQQ and terminal ubiquinol cytochrome $b_{3}$ oxidase fused expression 
plasmid was constructed by the $p E A S Y$-Uni seamless cloning and assembly kit CU101 (TransGen, China). The PCR-amplified promoter $\mathrm{P}_{0169}, p q q A B C D E$, and $t l d D$ were cloned into the $\mathrm{XbaI}$ site of the shuttle vector $\mathrm{pUCpr}$, which resulted in the plasmid pUCpr-T1- $\mathrm{P}_{0169}$ and pUCpr-T2- $\mathrm{P}_{0169}$. Then the cyoBACD (GOX1911-1914) was inserted the $\mathrm{XbaI}$ and $\mathrm{KpnI}$ site of pUCpr-T1-P 0169 and pUCpr-T2- $\mathrm{P}_{0169}$ to generate the fusion expressed plasmid pUCpr-T3 and pUCpr-T4, respectively. After verification of the accuracy of the plasmid by the sequencing, the fusion plasmid was transferred in the recombinant strain G. oxydans ZJU3 by electroporation [46] and selected for a gentamycin-kanamycin resistant phenotype, generated G. oxydans ZJU6 and G. oxydans ZJU7.

\section{Measurements of enzyme activity and protein concentration}

For the purpose of preparation of the cell crude extract and membrane fraction, a single colony of the G. oxydans strain was pre-incubated in MP medium. The G. oxydans cells were harvested by centrifugation $(10,000 \times$ g, $5 \mathrm{~min}, 4{ }^{\circ} \mathrm{C}$ ) and resuspended in $20 \mathrm{~mL} 50 \mathrm{mM}$ sodium phosphate buffer ( $\mathrm{pH}$ 6.0). The cells were disrupted with an ultrasonifier (JY92-2D, Xinzhi, NingBo) for 50 cycles $(2000 \mathrm{w}, 3 \mathrm{~s}$ sonication, $5 \mathrm{~s}$ pause) on ice. The cell debris were removed by centrifugation at $5500 \times \mathrm{g}$ for $20 \mathrm{~min}$ at $4{ }^{\circ} \mathrm{C}$ and the supernatant was used as the crude extract. For the preparation of membranes, the supernatant was centrifuged for $60 \mathrm{~min}$ at $180,000 \times \mathrm{g}$ at $4{ }^{\circ} \mathrm{C}$. The resulting sediments were collected and resuspended into $50 \mathrm{mM}$ sodium phosphate buffer ( $\mathrm{pH}$ 6.0), and used as the membrane fraction.

Enzyme activities were determined using a spectrophotometer (Uvmini-1240 SHIMADZU'). Substratedependent changes of redox states of artificial electron acceptors (2, 6-dichlorophenolindophenol, DCPIP, Sigma) were determined at $600 \mathrm{~nm}$ and $30{ }^{\circ} \mathrm{C}$. The basal reaction mixture contained $50 \mathrm{mM}$ PBS pH 6.0, $0.25 \mathrm{mM}$ DCPIP, and $0.325 \mathrm{mM}$ phenazine methosulphate (PMS, Sigma), which was prepared and pre-warmed to $30{ }^{\circ} \mathrm{C}$ before the assay. Measurements were performed in a cuvette with a 1 -cm light path containing a $0.8-\mathrm{mL}$ basal reaction mixture and $10 \mu \mathrm{L}$ enzyme pre-incubated at $30{ }^{\circ} \mathrm{C}$ for $5 \mathrm{~min}$. The reaction was started by adding $20 \mu \mathrm{L}$ of a $2.0 \mathrm{M}$ gluconate solution. One unit of enzyme activity (U) was defined as the amount of enzyme that can catalyze the conversion of $1 \mu \mathrm{M}$ DCPIP per min at $30{ }^{\circ} \mathrm{C}$. The concentration of proteins was determined with the Pierce ${ }^{\mathrm{m} m} \mathrm{BCA}$ assay kit.

\section{Quantitative real-time PCR (RT-PCR)}

Cells were harvested at an $\mathrm{OD}_{600}$ of 2.5 at room temperature and immediately frozen in liquid nitrogen. Cells were then stored at $-80{ }^{\circ} \mathrm{C}$ until RNA extraction.
Total RNA was extracted with RNAiso ${ }^{\text {ma }}$ Plus from Takara (Dalian, China) and treated with RNase-free DNase. Following chloroform extraction step, RNA was precipitated with isopropanol and the pellet washed twice in $75 \%$ ethanol. After air-drying, RNA was resuspended in RNase-free water. The quantity of total RNA was verified using an Eppendorf Biophotometer (Eppendorf, Hamburg, Germany). The cDNA was synthesized from the total RNA using a PrimeScript RT Reagent Kit (Perfect Real Time) (Takara) according to the manufacturer's protocol. The products were quantified via realtime PCR with StepOnePlus ${ }^{\text {TM }}$ Real-Time PCR System (Applied Biosystems, USA) using primer RTsldh_F/ RTsldh_R. The 16S rRNA gene was used as internal standard based on the primer RT16S_F/RT16S_R.

\section{Characterization of respiration activity and $\mathrm{H}^{+} / \mathrm{O}$ measurements}

Cultivation of G. oxydans strains was performed and the respiration activity was measured by the exhaust gas analysis system, such as the oxygen transfer rate (OTR), carbon dioxide transfer rate (CTR). The number of $\mathrm{H}^{+}$ moved upon respiration $\left(\mathrm{H}^{+} / \mathrm{O}\right.$ ratio) is principally important for the efficiency of cellular ATP production. Hence the $\mathrm{H}^{+} / \mathrm{O}$ ratio of bacterial cells have been measured to evaluate the efficiency of the respiratory chain. The $\mathrm{H}^{+} / \mathrm{O}$ and terminal ubiquinol oxidase activity were measured using a method previously reported in the literature [36].

\section{Batch fermentations}

Batch and fed-batch fermentations were conducted in a $15 \mathrm{~L}$ stirred tank bioreactor (Fus-D; Guoqiang Bioengineering Equipment Co., Ltd, Shanghai, China) with $9 \mathrm{~L}$ of the initial medium, which was composed of $0.41 \mathrm{~g} / \mathrm{L}$ $\left(\mathrm{NH}_{4}\right)_{2} \mathrm{SO}_{4}, 0.1 \mathrm{~g} / \mathrm{L}\left(\mathrm{NH}_{4}\right)_{2} \mathrm{HPO}_{4}, 0.01 \mathrm{~g} / \mathrm{L} \quad \mathrm{MgSO}_{4}$. $7 \mathrm{H}_{2} \mathrm{O}, 3.0 \mathrm{~g} / \mathrm{L}$ corn steep liquor paste and $100-150 \mathrm{~g} / \mathrm{L}$ glucose (depending on the experiment) [19]. The $\mathrm{CaCO}_{3}$ $(20 \mathrm{~g} / \mathrm{L})$ was sterilized separately and then added to the medium. The seed culture was prepared by inoculation of a single colony into a 5-mL MP medium tube, then into $200 \mathrm{~mL}$ of fresh seed medium in 500-mL flasks and cultivated on a rotary shaker at $220 \mathrm{rpm}$ for $16 \mathrm{~h}$. The seed culture $(5 \%, \mathrm{v} / \mathrm{v})$ was then inoculated into the fermentation medium and the fermentation was carried out at $30{ }^{\circ} \mathrm{C}$ and $\mathrm{pH}$ was controlled at 5.0 by automatic addition of $5 \mathrm{M} \mathrm{NaOH}$. In order to examine whether PQQ could enhance the 5-KGA production in engineered strains, different amount of PQQ $(0 \mu \mathrm{g} / \mathrm{L}$, $100 \mu \mathrm{g} / \mathrm{L}, 200 \mu \mathrm{g} / \mathrm{L}, 500 \mu \mathrm{g} / \mathrm{L}$ ) was exogenously added to the mixed cultures at the beginning of the fermentation process, and the 5-KGA concentrations were measured after $64 \mathrm{~h}$. 


\section{Fed-batch fermentation}

In this study, optimization of the $\mathrm{pH}$ condition was examined in a medium containing $100 \mathrm{~g} / \mathrm{L}$ glucose as the initial substrate. The $\mathrm{pH}$ was controlled as 5.5, 5.0, 4.5, and 4.0 and the glucose and 5-KGA were detected. Hence, a two-stage $\mathrm{pH}$ control strategy was employed. In the first stage of glucose oxidized to GA, then shifted to 4.5 in the process of 5-KGA production. In further experiment, fed-batch culture was performed. When the fermentation was began, the initial volume was $6 \mathrm{~L}$ and the glucose concentration was $100 \mathrm{~g} / \mathrm{L}$, then $2 \mathrm{~L}$ of the feed medium containing $1400 \mathrm{~g}$ glucose was added when the concentration of glucose turned to $30 \mathrm{~g} / \mathrm{L}$ and maintained between 30 and $40 \mathrm{~g} / \mathrm{L}$.

\section{Analysis}

Samples were centrifuged at 12,000 g for $2 \mathrm{~min}$, and the supernatant was passed through a $0.22 \mu \mathrm{m}$ filter. The residual glucose concentration was determined by a bioanalyzer (SBA-40D, Shandong Academy of Sciences, China) after dilution to an appropriate concentration. The GA and 5-KGA in the fermentation broth were analyzed by high-performance liquid chromatography (HP1100, Agilent 1100 series) using a RSpak DE-613 column (Shodex, Japan), with $2 \mathrm{mM} \mathrm{HClO}_{4}$ as the mobile phase at a flow rate of $0.5 \mathrm{~mL} / \mathrm{min}$ and a UV absorption of $210 \mathrm{~nm}$. Acetic acid was detected by GC (Agilent 6820 series). The biomass dry cell weight was determined by applying membrane filtration. Before filtration, the $\mathrm{CaCO}_{3}$ was removed by reaction with $\mathrm{HCl}$. The concentration of PQQ in the culture supernatants was measured according to the literature [24]. All experiments were performed in triplicate and the Origin 8.0 software package was used for statistical analysis. Analysis of variance was performed. Each data point represents the mean \pm SD from triplicate experiments.

\section{Ethics approval}

Not applicable.

\section{Consent for publication}

Not applicable.

\section{Availability of data and materials}

The Nucleic acids sequences supporting the conclusions of this article is available in the GenBank (National Center for Biotechnology Information) [http://www.ncbi.nlm.nih.gov/genbank].

Genome of Gluconobacter oxydans DSM2343 Accession: NC_006677.1 par-rep gene sequence from pGOX3 of Gluconobacter oxydans DSM2343 Accession: CP000006, pBBR1MCS5 plasmid Accession: U25061.

\section{Abbreviations used}

2-KGA: 2-keto-D-gluconate; 5-KGA: 5-keto-D-gluconate; DCPIP: 2, 6dichlorophenolindophenol; DCW: dry cell weight; DOT: dissolved oxygen tension; GA: gluconic acid; PQQ: pyrroloquinoline quinone.

Competing interests

All authors declare that they have no competing interests.

\section{Authors' contributions}

$J Y, M W$ and $J L$ conceived and designed the study. JY and $J L$ drafted the manuscript. LY participated in the project design and manuscript preparation. All authors read and approved the final manuscript.

\section{Authors' information}

$J Y$, Ph.D. student of Zhejiang University. MW, JL, and LY are staffs of Zhejiang University. The address is as follow: Key Laboratory of Biomass Chemical Engineering of Ministry of Education, Department of Chemical and Biological Engineering, Zhejiang University, Hangzhou 310027, China

\section{Acknowledgments}

This study was financially supported by the National High Technology Research and Development Program of China (863 Program, No. 2014AA022105) and the Zhejiang Leading Team of S \& T Innovation Program (2011R50002).

Received: 3 March 2016 Accepted: 10 May 2016

Published online: 17 May 2016

\section{References}

1. Chandrashekar K, Felse PA, Panda T. Optimization of temperature and initial $\mathrm{pH}$ and kinetic analysis of tartaric acid production by Gluconobacter suboxydans. Bioprocess Eng. 1999;20:203-7.

2. DeBolt S, Cook DR, Ford CM. L-tartaric acid synthesis from vitamin C in higher plants. Proc Natl Acad Sci U S A. 2006;103:5608-13.

3. Elfari M, Ha SW, Bremus C, Merfort M, Khodaverdi V, Herrmann U. A Gluconobacter oxydans mutant converting glucose almost quantitatively to 5-keto-D-gluconic acid. Appl Microbiol Biotechnol. 2005;66:668-74.

4. Matzerath I, Kläui W, Klasen R, Sahm H. Vanadate catalyzed oxidation of 5keto-D-gluconic acid to tartaric acid: the unexpected effect of phosphate and carbonate on rate and selectivity. Inorg Chim Acta. 1995;237:203-5.

5. Li X, Xu TC, Ma XH, Guo KP, Kai L, Zhao YH. Optimization of culture conditions for production of cis-epoxysuccinic acid hydrolase using response surface methodology. Bioresource Technol. 2008;99:5391-6.

6. Orru RVA, Archelas A, Furstoss R, Faber K. Epoxide hydrolases and their synthetic applications. Adv Biochem Engin/Biotechnol. 1999;63:145-67.

7. Willaert $R$, Vuyst LD. Continuous production of L-(+)-tartaric acid from cisepoxysuccinate using a membrane recycle reactor. Appl Microbiol Biotechnol. 2006:71:155-63.

8. Klasen R, Bringer-Meyer S, Sahm H. Incapability of Gluconobacter oxydans to produce tartaric acid. Biotechnol Bioeng. 1992;40:183-6.

9. Klasen R, Bringer-Meyer S, Sahm H. Biochemical characterization and sequence analysis of the gluconate: NADP 5-oxidoreductase gene. J Bacteriol. 1995;177:2637-43.

10. Prust $C$, Hoffmeister $M$, Liesegang $H$, Wiezer A, Fricke WF, Ehrenreich A. Complete genome sequence of the acetic acid bacterium Gluconobacter oxydans. Nat Biotechnol. 2005;23:195-200.

11. Kataoka N, Matsutani M, Yakushi T, Matsushita K. Efficient production of 2, 5-diketo-D-gluconate via heterologous expression of 2ketogluconate dehydrogenase in Gluconobacter japonicas. Appl Environ Microbiol. 2015;81:3552-60.

12. Matsushita K, Shinagawa E, Adachi O, Ameyama M. Reactivity with ubiquinone of quinoprotein D-glucose dehydrogenase from Gluconobacter suboxydans. J Biochem. 1989;105:633-7.

13. Shinagawa E, Ano Y, Yakushi T, Adachi O, Matsushita K. Solubilization, purification, and properties of membrane-bound D-glucono- $\delta$-lactone hydrolase from Gluconobacter oxydans. Biosci Biotechnol Biochem. 2009;73:241-4

14. Toyama H, Furuya N, Saichana I, Ano Y, Adachi O, Matsushita K. Membrane bound, 2-keto-D-gluconate yielding D-gluconate dehydrogenase from Gluconobacter dioxyacetonicus IFO 3271: molecular properties and gene disruption. Appl Environ Microbiol. 2007;73:6551-6. 
15. Shinagawa E, Matsushita K, Adachi O, Ameyama M. Evidence for electron transfer via ubiquinone between quinoproteins D-glucose dehydrogenase and alcohol dehydrogenase of Gluconobacter suboxydans. J Biochem. 1990;107:863-7.

16. Toyama H, Mathews FS, Adachi O, Matsushita K. Quinohemoprotein alcohol dehydrogenase: structure, function, and physiology. Arch Biochem Biophys. 2004;428:10-21.

17. Saichana I, Moonmangmee D, Adachi O, Matsushita K, Toyama H. Screening of thermotolerant Gluconobacter strains for production of 5-keto-D-gluconic acid and disruption of flavin adenine dinucleotide-containing D-gluconate dehydrogenase. Appl Environ Microbiol. 2009;75:4240-7.

18. Merfort M, Herrmann U, Ha SW, Elfari M, Bringer-Meyer S, Görisch H. Modification of the membrane-bound glucose oxidation system in Gluconobacter oxydans significantly increases gluconate and 5-keto-Dgluconic acid accumulation. Biotechnol J. 2006;5:556-63.

19. Merfort M, Hermann U, Bringer-Meyer S, Sahm H. High-yield 5-keto-Dgluconic acid formation is mediated by soluble and membrane-bound gluconate-5-dehydrogenase of Gluconobacter oxydans. Appl Microbiol Biotechnol. 2006;73:443-51.

20. Ano Y, Shinagawa E, Adachi O, Toyama H, Yakushi T, Matsushita K. Selective, high conversion of D-glucose to 5-keto-D-gluconate by Gluconobacter suboxydans. Biosci Biotechnol Biochem. 2011;75:586-9.

21. Yuan JF, Wu MB, Lin JP, Yang LR. Enhancement of 5-keto-D-gluconate production by a recombinant Gluconobacter oxydans using a dissolved oxygen control strategy. J Biosci Bioeng 2015, http://dx.doi.org/10.1016/j. jbiosc.2015.12.006.

22. Shi LL, Li KF, Zhang H, Liu X, Lin JP, Wei DZ. Identification of a novel promoter gHp0169 for gene expression in Gluconobacter oxydans. J Biotechnol. 2014;175:69-74.

23. Gao LL, Hu YD, Liu J, Du GC, Zhou JW, Chen J. Stepwise metabolic engineering of Gluconobacter oxydans WSH-003 for the direct production of 2-keto-L-gulonic acid from D-sorbitol. Metab Eng. 2014;24:30-7.

24. Du J, Bai W, Song H, Yuan YJ. Combinational expression of sorbose/ sorbosone dehydrogenases and cofactor pyrroloquinoline quinone increases 2-keto-L-gulonic acid production in Ketogulonigenium vulgareBacillus cereus consortium. Metab Eng. 2013;19:50-6.

25. Richhardt J, Luchterhand B, Bringer S, Büchs J, Bott M. Evidence for a key role of cytochrome $\mathrm{bO}_{3}$ oxidase in respiratory energy metabolism of Gluconobacter oxydans. J Bacteriol. 2013;195:4210-20.

26. Xu S, Wang XB, Du GC, Zhou JW, Chen J. Enhanced production of Lsorbose from L-sorbitol by improving the mRNA abundance of sorbitol dehydrogenase in Gluconobacter oxydans WSH-003. Microb Cell Fact. 2014;13:146-52.

27. Kallnik V, Meyer M, Deppenmeier U, Schweiger P. Construction of expression vectors for protein production in Gluconobacter oxydans. J Biotechnol. 2010;150:460-5.

28. Richhardt J, Bringer S, Bott M. Role of the pentose phosphate pathway and the entner-doudoroff pathway in glucose metabolism of Gluconobacter oxydans 621H. Appl Microbiol Biotechnol. 2013;97:4315-23.

29. Krajewski V, Simić P, Mouncey NJ, Bringer S, Sahm H, Bott M. Metabolic engineering of Gluconobacter oxydans for improved growth rate and growth yield on glucose by elimination of gluconate formation. Appl Environ Microbiol. 2010;76:4369-76.

30. Soini J, Ukkonen K, Neubauer P. High cell density media for Escherichia coli are generally designed for aerobic cultivations consequences for large-scale bioprocesses and shake flask cultures. Microb Cell Fact. 2008;7:26-36.

31. Dauner M, Sonderegger M, Hochuli M, Szyperski T, Wüthrich K, Hohmann HP. Intracellular carbon fluxes in riboflavin producing Bacillus subtilis during growth on two-carbon substrate mixtures. Appl Environ Microbiol. 2002;68: 1760-71.

32. Hölscher T, Görisch H. Knockout and overexpression of pyrroloquinoline quinone biosynthetic genes in gluconobacter oxydans $621 \mathrm{H}$. J Bacteriol. 2006;188:7668-76.

33. San KY, Bennett GN, Berrios-Rivera SJ, Vadali RV, Yang YT, Horton E. Metabolic engineering through cofactor manipulation and its effects on metabolic flux redistribution in Escherichia coli. Metab Eng. 2002;4:182-92.

34. Sánchez AM, Bennett GN, San KY. Effect of different levels of NADH availability on metabolic fluxes of Escherichia coli chemostat cultures in defined medium. J Biotechnol. 2005;117:395-405.
35. Chemler JA, Fowler ZL, McHugh KP, Koffas MAG. Improving NADPH availability for natural product biosynthesis in Escherichia coli by metabolic engineering. Metab Eng. 2010;12:96-104.

36. Minohara S, Sakamoto J, Sone N. Improved $\mathrm{H}^{+} / \mathrm{O}$ ratio and cell yield of Escherichia coli with genetically altered terminal quinol oxidases. J Biosci Bioeng. 2002;93:464-9.

37. Lawford $\mathrm{HG}$, Haddock BA. Respiration-driven proton translocation in Escherichia coli. Biochem J. 1973;136:217-20.

38. Tran QH, Bongaerts J, Vlad D, Unden G. Requirement for the proton-pumping $\mathrm{NADH}$ dehydrogenase I of Escherichia coli in respiration of $\mathrm{NADH}$ to fumarate and its bioenergetic implications. Eur J Biochem. 1997;244:155-60.

39. Puustinen A, Finel M, Virkki M, Wikström M. Cytochrome $o$ (bo) is a proton pump in Paracoccus denitrificans and Escherichia coli. FEBS Lett. 1989;249:163-7.

40. Meyer M, Schweiger P, Deppenmeier U. Effects of membrane-bound glucose dehydrogenase overproduction on the respiratory chain of Gluconobacter oxydans. Appl Microbiol Biotechnol. 2013;97:3457-66.

41. Qizi GN, Parshad R, Verma V, Chopra CL, Buse R, Träger M. Diketo-gluconate fermentation by Gluconobacter oxydans. Enzyme Microb Technol. 1991;13: 504-7.

42. Hanke T, Richhardt J, Polen T, Sahm H, Bringer S, Bott M. Influence of oxygen limitation, absence of the cytochrome bc(1) complex and low pH on global gene expression in Gluconobacter oxydans $621 \mathrm{H}$ using DNA microarray technology. J Biotechnol. 2012;157:359-72.

43. McNeil B, Harvey L. Energy well spent on a prokaryotic genome. Nat Biotechnol. 2005;23:186-7.

44. Zhang L, Lin JP, Ma YS, Wei DZ, Sun M. Construction of a novel shuttle vector for use in Gluconobacter oxydans. Mol Biotechnol. 2010;46:227-33.

45. Kovach ME, Elzer PH, Hill DS, Robertson GT, Farris MA, Roop RM. Four new derivatives of the broad-host-range cloning vector pBBR1MCS carrying different antibiotic resistance cassettes. Gene. 1995;166:175-6.

46. Mostafa HE, Heller KJ, Geis A. Cloning of Escherichia coli lacZ and lacY genes and their expression in Gluconobacter oxydans and acetobacter liquefaciens. Appl Environ Microbiol. 2002;68:2619-23.

\section{Submit your next manuscript to BioMed Central and we will help you at every step:}

- We accept pre-submission inquiries

- Our selector tool helps you to find the most relevant journal

- We provide round the clock customer support

- Convenient online submission

- Thorough peer review

- Inclusion in PubMed and all major indexing services

- Maximum visibility for your research

Submit your manuscript at www.biomedcentral.com/submit 